\title{
One-year follow-up of patients with long-lasting post-herpetic neuralgia
}

\author{
Francesca Pica ${ }^{1 \dagger}$, Antonio Gatti ${ }^{2, \wedge \dagger}$, Marco Divizia ${ }^{2}$, Marzia Lazzari ${ }^{2}$, Marco Ciotti ${ }^{3}$, Alessandro Fabrizio Sabato ${ }^{2}$ \\ and Antonio Volpi ${ }^{4^{*}}$
}

\begin{abstract}
Background: Recent information on epidemiology and management of post-herpetic neuralgia (PHN), a painful complication of zoster, is scarce.

Methods: This study was conducted at the Pain Clinic of the Policlinico Tor Vergata, Rome, Italy, on eighty-five immunocompetent patients with a clinical diagnosis of PHN. At enrollment (time $0, \mathrm{TO}$ ), the patients were interviewed by physicians to obtain demographic data and information about their zoster clinical history and underwent a blood test for VZV-DNA research. DN4 and SF-12 questionnaires were used to assess the neuropathic nature of pain and the overall health status, respectively. A one-year follow-up was planned for enrolled cases, who were visited at regular intervals of at least 3 months.

Results: At T0 all the patients were at least 6 months from the episode of acute zoster and still presented with intense pain (mean VAS $=6.7$; mean DN4 = 5.7). Using antivirals within 72 hours from the rash onset was associated to a significant reduction of pain at T0 ( $p=0.006$ vs untreated patients). Only $2.6 \%$ of patients treated with antivirals during acute zoster but $18.6 \%$ of the untreated ones presented with neuropathic pain at T12 ( $p=0.007$ ), even though the two groups were similar at T0. VZV-DNA was found in 5 out of the 50 available blood samples. At the last follow-up visit, PCS and MCS scores of the PHN patients were found to be recovered over those of the historical age-matched healthy controls. Undesirable side effects of analgesic therapies were observed in 15.3 to $28.8 \%$ of the patients.

Conclusions: Patients who six months after acute zoster still have significant neuropathic pain, have a high probability of suffering from chronic pain in the subsequent months/years. The initial antiviral treatment has a significant impact on the pain. Current strategies of analgesic therapy are effective to achieve relief of pain in PHN patients, but they are burdened with heavy and undesirable side effects.
\end{abstract}

Keywords: Chronic pain, Herpes zoster (HZ), Post-herpetic neuralgia (PHN), Quality of life

\section{Background}

Post-herpetic neuralgia (PHN) is the most challenging and debilitating complication of herpes zoster $(\mathrm{HZ})$ in immunocompetent hosts. It is characterized by constant or intermittent burning, itching or aching, with paroxysmal or lancinating pain. Other primary characteristic, such as numbness, tingling and allodynia, also contribute to the burden of PHN. Pain intensity at the rash onset, age, rash severity, length of prodromal pain and cranial localization

\footnotetext{
* Correspondence: volpi@med.uniroma2.it

${ }^{\wedge}$ Deceased

${ }^{\dagger}$ Equal contributors

${ }^{4}$ Dipartimento di Scienze Cliniche e Medicina Traslazionale, Università di

Roma Tor Vergata, Via Montpellier, 1 - 00133, Rome, Italy

Full list of author information is available at the end of the article
}

are more frequently reported as predictors of PHN [1-14]. Several issues concerning diagnosis, prediction and prevention of PHN need, however, to be clarified in view of recent contributions [15-20].

Despite advances in antiviral therapy during acute $\mathrm{HZ}$ and the more recent introduction of vaccination against Varicella-zoster virus (VZV) [21], PHN continues to be a significant clinical problem, with up to $25 \%$ of patients over 60 years developing persistent neuropathic pain following acute HZ [22-24]. The estimated incidence of PHN varies with its definition [25-30]. PHN can persist, in some individuals, for months or years after the $\mathrm{HZ}$ rash has healed, causing suffering for the patient and a burden of economic cost on patient, care givers, and 
healthcare providers. Studies vary widely in the reporting of the duration of persistent pain [31]. Helgason et al. [32] found that of 13 subjects with persistent pain 12 months after HZ, 6 still reported pain after 6.3 years. In one study of patients aged over 65 years, the mean duration of pain was 3.3 years, and ranged from 3 months to more than 10 years [33]. A few recent prospective studies report on the persistence of symptoms up to and over 12 months after $\mathrm{HZ}$ onset. In detail, Bouhassira et al. [34] reported the presence of zoster-related pain in 6\% of 1032 patients 12 months after HZ. McKendrick et al. [35] found that of 158 subjects assessed 9 years after HZ, 21\% had experienced any pain during the past year; of these, $47 \%$ had been pain-free at the time of discharge from the acute study. This is the reason why, in the last years, PHN is emerging as a preferred clinical trial model for chronic neuropathic pain [36].

The treatment of PHN is presently based on a well characterized array of drugs and drug associations with proved efficacy, including tricyclic antidepressants, the antiepileptic drug gabapentin, pregabalin and opioids, with some evidence also for topical lidocaine [36]. It remains still unsatisfactory, however, in a substantial proportion of patients, especially those with many comorbidities and more intense pain at $\mathrm{HZ}$ presentation [36].

Acute $\mathrm{HZ}$ and consequently PHN particularly afflicts the immunocompromised and elderly patients, a fact that has serious implications for health-care delivery in the context of ageing populations in the developed world and the worldwide spread of HIV disease. Left untreated, PHN can become a severe and debilitating condition affecting all aspects of a patient's life [37].

The present report focus on the actual impact of diagnosis and management of PHN. In detail, the correlations existing between demographic and clinical characteristics of patients, the possible utility of VZV-DNA research in blood, and the efficacy of treatments for pain relief on the quality of life of PHN patients have been examined.

\section{Methods}

\section{Study population and design}

Patients with a clinically diagnosed PHN, with pain over 3 VAS for at least 6 months after the onset of acute zoster, were consecutively enrolled at the Pain Clinic of the Policlinico Tor Vergata, Rome, Italy, and examined and treated between January 1, 2009 and November 15, 2010. The study was submitted to and received approval by the Independent Ethical Committee of the University of Rome "Tor Vergata".

Eighty-five immunocompetent patients with PHN gave written informed consent to be included in the study. They were interviewed by physicians to obtain demographic data (i.e. name, age, sex, race/ethnicity), memory of primary VZV infection and HZ history [presence of a prodrome (defined as pain before rash onset) and its duration (range 1 - over 3 days), extent of rash (rash involving 1,2 , or more than two dermatomes) and its localization, intensity of pain, presence of abnormal sensations (including tingle and allodynia) and/or itch, and antiviral therapy]. All data obtained from the interviews were recorded in database files.

Participants in the study also were asked to undergo a blood test for VZV DNA research at the time of enrollment. Blood sampling (5 $\mathrm{ml}$ whole blood per patient) was performed after an overnight fast. Whole blood samples were collected and DNA was extracted using a QIAamp DNA blood mini kit (Qiagen Ltd., United Kingdom) according to the manufacturer's instructions. The eluted DNA was stored at $-20^{\circ} \mathrm{C}$. Detection and quantification of VZV DNA were performed by using a VZV QPCR Alert kit (Nanogen Advanced Diagnostics, Torino, Italy). The cut-off of the method was 56 viral copies $/ \mathrm{ml}$ and below this level it is able to detect up to 10 copies/ $\mathrm{ml}$ of virus, if present.

Different tools were used to quantify and qualify pain in the enrolled PHN patients. Briefly, the intensity of pain was evaluated using a visual analog scale (VAS) of $10 \mathrm{~cm}$ in length that was graduated from " 0 " to " 10 ," where " 0 " represented no pain and "10" the most unbearable pain.

The DN4 questionnaire (which stands for Douleur Neuropathique en 4 Questions) was used to estimate the probability of neuropathic pain in our PHN patients. It consists of 10 items subdivided into two parts: sensory descriptors (seven items) and signs relating to the sensory examination (three items). The presence of neuropathic pain was taken to be the dependent variable and needed to reach a score of at least 4 out 10 , while non-neuropathic pain presented scores of less than 4 out 10. This questionnaire has been well validated in a number of studies [37-39].

The SF-12 questionnaire was also used in the medical interviews [40]. It is a generic short form health survey developed in the USA from the original SF-36, which produces two summary measures evaluating physical and mental self-perceived health that are interchangeable with those from the SF-36. SF-12 has been successfully tested in nine Western European countries, included Italy, on large samples of the general population, where it has proved its brevity, comprehensiveness, reliability, validity and cross-cultural applicability $[40,41]$.

A one-year follow-up was planned for all the enrolled cases, who were visited at least every 3 months. Patients were subjected to drug therapy according to the protocols currently in use at international level $[42,43]$. Treatment of pain was chosen on the basis of the international specific guidelines [36] paying particular attention to the presence of eventual comorbidities, drug interactions with drugs already used in the therapy and potential side effects. 


\section{Statistical analysis}

Statistical analysis and data processing were performed using SPSS software - version 20 for Windows ${ }^{\mathrm{TM}}$. All two-sided statistical tests were performed with a 5\% significance level. Quantitative variables were analysed by descriptive statistics including mean values, standard deviation, median, minimum and maximum. Clinical and demographic characteristics were analysed by Chi-square test and Analysis of variance (ANOVA).

\section{Results}

\section{Study population}

The demographic and clinic characteristics of the PHN patients enrolled in the study are listed in Table 1. Overall, the group consisted of 85 immunocompetent individuals (50 female and 35 male) who had received a clinical diagnosis of $\mathrm{HZ}$ at least 6 months before the enrollment, and whose median age was 74.5 years (range 47-92) for female and 77 years (range 41-90) for male. All of them were Caucasian Italians and out-patient

Table 1 Demographic characteristics and herpes zoster history of patients with post-herpetic neuralgia

\begin{tabular}{|c|c|c|}
\hline & Female & Male \\
\hline Number & 50 & 35 \\
\hline Age & $N(\%)$ & N (\%) \\
\hline$<50$ & $2(4)$ & $1(3)$ \\
\hline $51-60$ & $4(8)$ & $3(9)$ \\
\hline $61-70$ & $9(18)$ & $2(6)$ \\
\hline $71-80$ & $18(36)$ & $13(27)$ \\
\hline$>80$ & $16(32)$ & $16(46)$ \\
\hline Median (range) & $74.5(47-92)$ & $77(41-90$ \\
\hline \multicolumn{3}{|c|}{ Prodromal pain } \\
\hline$<1$ day & $29(58)$ & $27(77)$ \\
\hline $1-3$ days & $10(20)$ & $2(6)$ \\
\hline 3 days & $11(22)$ & $6(17)$ \\
\hline \multicolumn{3}{|c|}{ Localization of rash } \\
\hline Cranial & $9(18)$ & $10(29)$ \\
\hline Cervical & $6(12)$ & $4(11)$ \\
\hline Thoracic & $24(48)$ & $13(37)$ \\
\hline Lumbar & $11(22)$ & $8(23)$ \\
\hline \multicolumn{3}{|l|}{ Severity of rash } \\
\hline Mild & $7(14)$ & $4(11)$ \\
\hline Moderate & $22(44)$ & $14(40)$ \\
\hline Intense & $16(32)$ & $15(43)$ \\
\hline Severe & $5(10)$ & $2(6)$ \\
\hline \multicolumn{3}{|l|}{ Therapy } \\
\hline No & $23(46)$ & $20(57)$ \\
\hline Yes & $27(54)$ & $15(43)$ \\
\hline
\end{tabular}

at the Pain Clinic of the Policlinico Tor Vergata, Rome, Italy.

The information on age, gender, $\mathrm{HZ}$ diagnosis and history, the overall health status and the immune status were collected by medical interview and visit at the time of enrollment in the study. Immune status was determined on the basis of the absence of specific conditions or treatments, i.e. active cancer, solid organ transplant, AIDS, chronic corticosteroid use, or other immunosuppressive treatments for autoimmune diseases or other conditions.

\section{Characteristics and correlates of pain}

All the patients, in both gender categories, reported to have had prodromal pain and abnormal sensations in the days (from 1 to 3 ) preceding the $\mathrm{HZ}$ rash onset. The rash localization was thoracic in 37 patients and cranial, cervical or lumbar in 19, 10 and 19 patients, respectively. The intensity of rash was moderate or severe in the $87 \%$ of patients and mild in the remaining $13 \%$. Only one half of the patients had received specific antiviral therapy prescription at the time of the $\mathrm{HZ}$ episode.

No statistically significant difference between the two gender groups in relation to the different parameters showed in Table 1 was found, with the only exception of the localization of rash (Chi-square: $\mathrm{p}<0.03)$.

Intense or very intense pain at the time of enrollment (i.e. time $0, \mathrm{~T} 0$ ) was reported by the majority of the patients (Figure 1). The patients reporting intense or very intense pain at T0 were equally distributed in the two gender categories $(p=0.22)$.

The median duration of pain (time from the rash onset), which was equal to 9 months (range 6-150) in the total population sample, was found to be longer for women than men, i.e. 12 months (range: 6-150) and 6 months (range: 6-72), respectively ( $p=0.067$ ).

The measures of the intensity and quality of pain at the time of enrollment and during the follow-up period are reported in Table 2, where patients with PHN have been grouped in three main age groups. The neuropathic nature of pain of participants in the study was assessed by the positivity of DN4 questionnaire, with scores greater than 4 in all the patients examined (Table 2). No difference by age group in relation to the parameter "pain" was found in our population sample (Table 2).

The use of antiviral therapy (i.e. Aciclovir, Valaciclovir, Famciclovir or Brivudin), starting within 72 hours from the rash onset, had been capable of inducing a significant reduction of pain (VAS average) at the time of enrollment at the Pain Clinic (T0) ( $p=0.006$ versus untreated patients). Further analyses confirmed a significant risk of having greater pain among patients who had not received antiviral therapy (Table 3 ). Moreover, only 2.6 percent of patients treated with antivirals during acute zoster but 


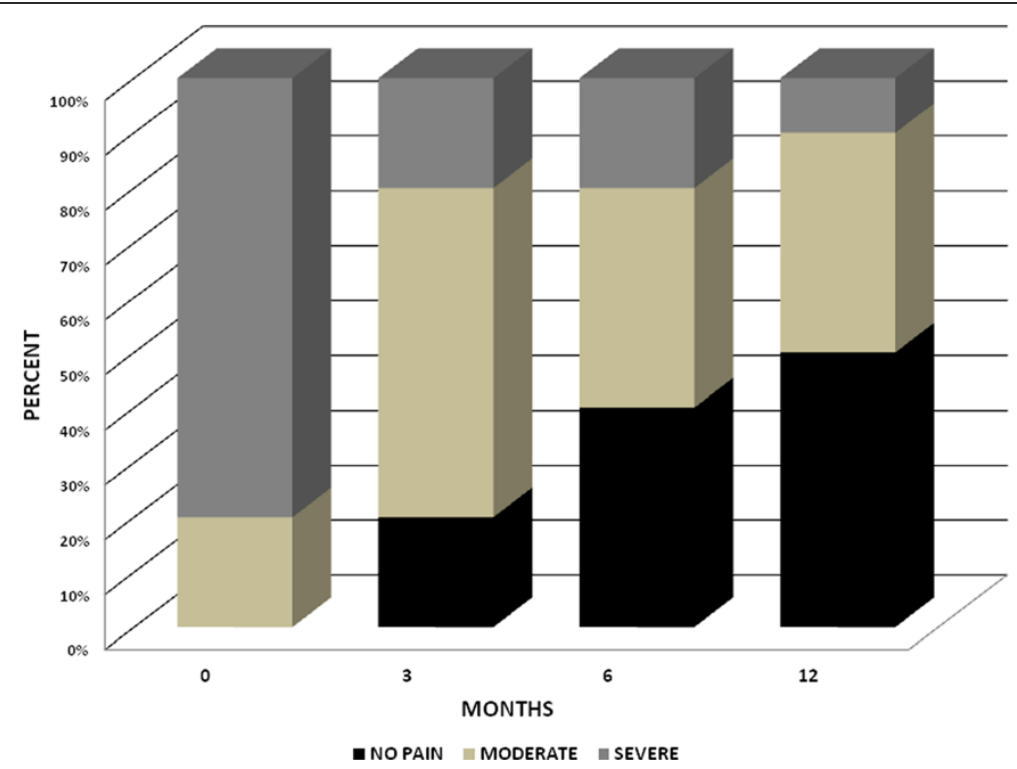

Figure 1 Intensity of pain in patients with post-herpetic neuralgia during the follow-up period.

18.6 percent of the untreated ones presented with neuropathic pain at T12 ( $p=0.007)$, even though no difference among the two groups had been observed at the time of enrollment (T0).

The efficacy of treatments for pain relief given to the patients during the overall period of examination, was demonstrated by a significant reduction of pain (VAS average) in the patients with PHN at all the times tested ( $\mathrm{p}<0.001$ ), without significant differences among different age groups (Table 2). However, several patients reported the occurrence of adverse effects related to these treatments [i.e. $19 / 85(22,4 \%)$ at 3 months, $13 / 85$ $(15,3 \%)$ at 6 months and $24 / 85(28,2 \%)$ at 12 months]. The main reported side effects were drowsiness, dizziness, ataxia, mild peripheral edema, and a worsening of cognitive impairment in elderly patients, in relation to treatments with the anticonvulsants, gabapentin and pregabalin; but also anticholinergic side effects such as sedation, orthostatic hypotension, cognitive decline, and constipation related to tricyclic antidepressant (TCA), or nausea, vomiting, dizziness, constipation, drowsiness and headache related to tramadol.

\section{PCS and MCS scores}

The Physical and Mental Health Composite Scale (PCS and MCS) scores of the patients enrolled in the study were measured by means of the SF-12 questionnaire. As expected, they varied as a function of the patients' age and were found to be lower in older individuals than in the younger ones (Table 4).

As shown in the Table 4, the PCS and MCS mean scores of our patients at the time of enrollment in the study were found to be sensibly lower than those measured in a large Italian population sample of healthy individuals [40], who were used as an historical age-matched control, thus confirming the devastating effects of PHN on the patients'quality of life in all the age groups.

At the time of enrollment, PCS mean scores of our patients were found to be lower in older patients than in the younger ones, whereas MCS mean scores appeared

Table 2 Characteristics of pain in patients with post-herpetic neuralgia

\begin{tabular}{|c|c|c|c|c|}
\hline & \multicolumn{3}{|l|}{ Age } & \multirow[b]{2}{*}{$P^{*}$} \\
\hline & 55-64 (15 pts) Mean \pm SD & $65-74$ (23 pts) Mean \pm SD & $>75$ (47 pts) Mean \pm SD & \\
\hline VAS at presentation & $6.80( \pm 1.265)$ & $6.83( \pm 1.230)$ & $6.62( \pm 1.649)$ & 0.879 \\
\hline VAS at 3 Months & $4.80( \pm 1.1568)$ & $4.00( \pm 2.412)$ & $3.96( \pm 1.769)$ & 0.355 \\
\hline VAS at 6 Months & $3.67( \pm 2.690)$ & $3.39( \pm 2.331)$ & $3.64( \pm 2.110)$ & 0.933 \\
\hline VAS at 12 Months & $2.27( \pm 1.944)$ & $2.28( \pm 1.864)$ & $2.85( \pm 2.167)$ & 0.487 \\
\hline DN4 at presentation & $5.80( \pm 1.265)$ & 5. $48( \pm 1.163)$ & $5.13( \pm 1.154)$ & 0.111 \\
\hline DN4 at 12 Months & $1.60( \pm 1.298)$ & $1.35( \pm 1.434)$ & $1.45( \pm 1.4)$ & 0.776 \\
\hline
\end{tabular}

*Statistical analysis of differences by Kruskal-Wallis Test. 
Table 3 Relative risk (RR) of having VAS lower than $\mathbf{5}$ for patients with post-herpetic neuralgia, who had been treated with Antivirals within $\mathbf{7 2}$ hours from the rash onset

\begin{tabular}{lll}
\hline & $\boldsymbol{p}$ & $\boldsymbol{R} \boldsymbol{R}(\mathrm{Cl}$ 95\%) \\
\hline VAS $<5$ at T0 & NS & $0.86(0.53-0.41)$ \\
VAS $<5$ at T3 & NS & $0.67(0.34-1.3)$ \\
VAS $<5$ at T6 & 0.017 & $0.42(0.17-1.0)$ \\
VAS $<5$ at T12 & 0.05 & $0.27(0.04-1.7)$ \\
\hline
\end{tabular}

to be quite similar (Table 4). The effectiveness of the treatments used to relieve pain during follow-up was demonstrated in all the PHN patients studied, through the observation of an apparent increase in both PCS and MCS scores, which were found even higher than those of the historical control (Table 4). Finally, in our study PCS and MCS mean scores did not differ depending on the gender of the patients examined (data not shown).

\section{VZV-DNA positivity in peripheral blood of patients with PHN}

Five out of the 50 available blood samples from the total of 84 PHN patients enrolled in this study were found to be positive for VZV DNA. Among them were 3 males (66, 81 and 88 years-old) and 2 females (48 and 75 years-old). Four of them had been affected by thoracic zoster, whereas the fifth was a 48 y-o woman who has presented with trigeminal zoster. The demographic and clinic characteristics of VZV DNA-positive PHN patients are summarized in the Table 5.

\section{Discussion}

This study confirms and extends previous observations about the natural history of zoster pain in a cohort of eighty-five consecutive immunocompetent PHN patients, who were followed prospectively after their admission at the Pain Clinic, Policlinico Tor Vergata, Rome, Italy, to receive proper medical therapy for pain relief.

At the time of study entry all the PHN patients were at least 6 months from the episode of acute zoster and still presented with intense or very intense pain (VAS $>6$ ), whose neuropathic nature was confirmed by the positivity of DN4 questionnaire, with scores greater than 4 in all the patients examined.

Our results clearly indicate that patients who still have significant neuropathic pain (VAS $\geq 6, \mathrm{DN} 4>4$ ) 6 months after the acute episode of zoster, have a high probability of suffering from chronic pain in the subsequent months/ years. This finding is in accordance with data from the international literature, since, on the basis of recently published prospective studies, six months is just emerging as a reliable time-threshold to discriminate, in the context of patients with PHN, between those with a more favorable or poor prognosis [44]. Consistently, Reda and coll. have shown that in a population of immunocompetent patients at high risk of PHN (for both older age and higher pain intensity), no subjects who were pain free at 6 months showed a recurrence of pain on subsequent visits [44].

We had shown previously that older age, greater acute pain intensity, greater rash extent and longer duration of prodromal pain are independent risk factors in the development of post-herpetic neuralgia, by analyzing the relationship between baseline and 6-month follow-up data in a sample of 219 Italian immunocompetent herpes zoster patients [15]. Even considering the possibility of recall bias, which is inherent to any study in which subjects are asked to recall events that may have occurred months or even years before [16], the results of the present study clearly confirm previous observation that severity of disease on acute herpes zoster presentation and older age are the best indicators of developing postherpetic neuralgia.

Table 4 Physical and mental health composite scale scores in patients with post-herpetic neuralgia

\begin{tabular}{|c|c|c|c|}
\hline & 55-64 (15 pts) Mean ( \pm SD) & $65-74$ (23 pts) Mean $( \pm S D)$ & $>75$ (47 pts) Mean $( \pm S D)$ \\
\hline MCS at the first visit & $34.86 \pm 5.3$ & $34.00 \pm 5.8$ & $33.1 \pm 8.0$ \\
\hline Historical controls* & $49.03 \pm 10.41$ & $47.79 \pm 11.10$ & $45.38 \pm 12.09$ \\
\hline MCS at 3 Months & $45.00 \pm 8.4$ & $41.2 \pm 7.0$ & $38.9 \pm 8.6$ \\
\hline MCS at 6 Months & $47.00 \pm 9.0$ & $45.00 \pm 9.1$ & $42.6 \pm 10.0$ \\
\hline MCS at 12 Months & $55.6 \pm 3.0$ & $53.3 \pm 4.7$ & $51.0 \pm 5.6$ \\
\hline PCS at the first visit & $37.9 \pm 7.6$ & $30.7 \pm 5.2$ & $29.6 \pm 4.9$ \\
\hline Historical controls* & $48.05 \pm 9.52$ & $44.04 \pm 10.71$ & $37.85 \pm 11.60$ \\
\hline PCS at 3 Months & $39.3 \pm 6.9$ & $37.9 \pm 5.4$ & $34.5 \pm 6.4$ \\
\hline PCS at 6 Months & $45.0 \pm 7.4$ & $41.5 \pm 7.9$ & $36.8 \pm 7.8$ \\
\hline PCS at 12 Months & $53.1 \pm 5.9$ & $49.4 \pm 5.2$ & $44.0 \pm 7.7$ \\
\hline
\end{tabular}

*Apolone G et al. QUESTIONARIO SULLO STATO DI SALUTE SF-12 - Versione italiana IRFMN 2005. Copyright 2001 Istituto di Ricerche Farmacologiche Mario Negri, Milano. 
Table 5 Demographic and clinical characteristics of patients with post-herpetic neuralgia and positive VZV viremia

\begin{tabular}{|c|c|c|c|c|c|}
\hline & $\begin{array}{l}\text { Patient n.1 } \\
\text { Male, } 66 \text { y-o }\end{array}$ & $\begin{array}{l}\text { Patient } n .2 \\
\text { Female, } 75 \text { y-o }\end{array}$ & $\begin{array}{l}\text { Patient n.3 } \\
\text { Male, } 88 \text { y-o }\end{array}$ & $\begin{array}{l}\text { Patient n.4 } \\
\text { Female, } 48 \text { y-o }\end{array}$ & $\begin{array}{l}\text { Patient n.5 } \\
\text { Male, } 81 \mathrm{y} \text {-o }\end{array}$ \\
\hline Prodromal pain & $<1$ day & $<1$ day & $<1$ day & $<1$ day & $<1$ day \\
\hline Rash onset & 6 months & 80 months & 7 months & 60 months & 36 months \\
\hline Rash localization & Thoracic & Thoracic & Thoracic & Trigeminal & Thoracic \\
\hline Rash intensity & Severe & Intense & Moderate & Moderate & Moderate \\
\hline Antiviral therapy & No & No & Yes & No & No \\
\hline VAS (T0) & 8 & 6 & 7 & 8 & 5 \\
\hline DN4 (TO) & 7 & 8 & 4 & 4 & 4 \\
\hline
\end{tabular}

Our previous studies did not establish female gender as a predictor of post-herpetic neuralgia [15]. Similarly, Dworkin and Schmader [45] did not find sex differences to be associated with the various aspect of herpes zoster, with the only exception being the intensity of acute pain which is higher in women than in men, as also confirmed by us previously [46]. It is conceivable that the earlier reported association between gender and long-term pain may have been a consequence of the fact that more women were in the higher age strata [47]. Also, among the 85 PHN subjects, who have been enrolled in the present study, there were more females than males as indeed is observed in the general population [15].

It is a matter of fact, however, that the median duration of pain before going to the pain clinic, which in the present study was equal to 9 months (range 6-150) in the total population sample, was found to be longer for women than men, i.e. 12 months (range: 6-150) and 6 months (range: 6-72), respectively, approaching the statistical significance and raising the question of gender differences with regard to the PHN.

Interestingly, a recent study shows that the incidence of CNS disease caused by alphaherpesvirus (VZV, HSV-1 and HSV-2) is associated with gender and its influence varies over the lifetime [48]. Starting from the observation that the susceptibility to and the severity of several viral infections is higher in men than in women [48], the Authors suggest that heightened antiviral responses typical of female gender, although effective for rapid virus clearance, can result in chronic/inflammatory pathologies, if excessively high or prolonged [49]. Their suggestion is based on the finding that compared to females, peripheral blood mononuclear cells from males produce lower amounts of IFN- $\alpha$ and higher amounts of the immunosuppressive cytokine IL-10 following stimulation with different toll-like receptors (TLRs) ligands or viruses, and some of these differences related with plasma levels of sex hormones [49]. Should this hypothesis be tested in a sufficiently large sample of patients with PHN, it could be evidence in favor of those who argue that protracted pain after $\mathrm{HZ}$ occurs either as a result of a severe neuronal injury at the time of zoster onset and/or a failure to recover normal neuronal function following an abnormal host's inflammatory response [44,50,51].

Although current guidelines recommend antiviral treatment within 72 hours from the rash onset in individuals aged over 50 years, with the aim of reducing the incidence and duration of PHN, only around one half of our PHN patients had received appropriate treatment. However, when considering that, as reported recently, $78.4 \%$ of zoster patients receive antiviral therapy in Italy [52], the herein reported results confirm that antiviral therapy of acute zoster is absolutely effective although not completely satisfactory in the prevention of PHN. Consistently, the group of our PHN patients who had been treated with antivirals during acute zoster, showed a reduced risk of higher pain during the follow-up and a significantly lower percentage of individuals with residual neuropathic pain at T12, compared with the untreated groups of PHN patients. Although the correlation is based, at least in part, on anamnestic data, which represents a possible bias, its meaning is quite clear. These findings potentially suggest less nerve damage [53], but can also be explained by the variability of clinical response and even more importantly by the efficacy of pain treatments. Therefore, these results need further confirmation on larger, prospective and randomized studies.

Quality of life is dramatically reduced in patients with long-lasting PHN. Consistently, PCS and MCS scores of our patients at the time of enrollment in the study were found to be sharply lower than those of a large Italian population sample of healthy individuals, who were used as an historical age-matched control. As expected, not only the MCS scores but even more the PCS scores of our patients varied as a function of the patients' age and were found to be lower in older individuals than in the younger ones. Also, it has to be emphasized that treatments used for pain relief seemed to have worked in all the patients enrolled in the study regardless of age groups or gender. This fact outlines the importance of a systematic and specialized approach to the problem of chronic pain in PHN patients. The nature of neuropathic 
pain in PHN is variable, so that it may be described as continuous or paroxysmal, evoked or spontaneous, burning or lancinating, and be associated with a range of other sensory abnormalities in the skin [54]. This variability in symptoms could imply that a variety of different pain mechanisms might be operating in different patients with PHN or in the same patient at different time points [54]. Therefore, treatment protocols should be optimised for individual patients on the basis of symptoms or even mechanisms [36]. Actually, no substantial evidence base exists to relate specific sets of symptoms or signs to the efficacy of specific drugs, and no simple validated methods exist to determine which neuropathic pain mechanism(s) may be operating in a single patient. Moreover, no single treatment has been shown to be completely effective for all sufferers of PHN, and combinations of analgesic drugs are usually required to achieve at least a partial relief of pain [36]. Tricyclic antidepressants, gabapentinoids and strong opioids are effective but are also associated with systemic adverse events that may limit their use in many patients, most notably those with significant medical comorbidities or advanced age [55]. Also, compliance of patients with treatment is an important factor in the clinical effectiveness of therapies, and a major factor governing compliance is withdrawal due to side effects (major harm).

Finally, our results do not allow us to confirm a clear relationship between the positivity/persistence of VZV viremia and PHN, since only 5 out of the 50 available blood samples from the PHN patients in the study were found positive for VZV DNA search. Other reports show comparatively higher percentages of VZV DNA-positivity in blood or saliva of patients affected by $\mathrm{HZ}$ and/or PHN $[18,56]$. It is worth mentioning, however, that searching for VZV DNA in blood of our PHN patients was performed only once in the course of the study. A possible reason for the discrepancy of the PCR results may be also related to the sensitivity of the different methods for VZV-DNA detection in blood. For VZV, as well as for other herpes viruses, a variety of methods, techniques and protocols have been used to measure viral load at many institutions [57]. However, because each institution monitors VZV load with its own "homebrew" system, detection techniques and viral load estimation values have not been standardized and results vary between different laboratories [56,57].

It seems that up to date, in spite of the large body of evidence available in the literature, there is still a need to gain new insights on the mechanism/s underlying PHN pathogenesis, which at present remains not fully elucidated. In detail, whether PHN pathogenesis is due to persistent productive virus infection in ganglia or to neuronal cell damage (i.e. altered excitability of ganglionic or even spinal cord neurons), is still controversial [58-67]. The possibility that protracted pain after zoster occurs either as a result of severe neuronal injury at the time of zoster onset or a failure to recover normal neuronal function $[29,30]$ is sustained by the very recent demonstration that there is only a modest recovery of sensory function and no anatomic recovery despite pain resolution in late follow-up of a group of PHN patients [44]. Further studies aimed at deepening our knowledge on PHN pathogenesis are currently in progress in our laboratories.

\section{Conclusions}

We report that patients who still have significant neuropathic pain six months after acute zoster present a high probability of suffering from chronic pain in the subsequent months/years. Antiviral therapy used within 72 hours from the rash onset reduces the risk of higher VAS in the follow-up. Current strategies of analgesic therapy are effective to achieve relief of pain in PHN patients, but they are burdened with heavy and undesirable side effects. PHN represents a major public health problem. In spite of the large body of evidence available in the literature, there is still a need to gain new insights on chronic pain, its burden and the efficacy of available treatments.

\section{Abbreviations}

PHN: Post-herpetic neuralgia; HZ: Herpes zoster; VZV: Varicella-Zoster virus; PCR: Polymerase chain reaction; DN4 questionnaire: Douleur Neuropathique en 4 Questions; PCS: Physical Health Composite Scale; MCS: Mental Health Composite Scale.

\section{Competing interests}

The authors declare that they have no competing interests.

\section{Authors' contributions}

AV and FP conceived and designed the study, performed most of the analyses on collected data, suggested and elaborated most od data interpretation criteria, and drafted the manuscript; AFS, ML and MD contributed to the study design, contributed substantially to the acquisition of data and to medical care of the enrolled patients; MC carried out laboratory assays and was involved in critical evaluation, interpretation and discussion of data. All authors read and approved the final version of the present manuscript.

\section{Acknowledgements}

The authors gratefully acknowledge all the PHN patients who participated in this study.

Antonio Gatti deceased on 2013. This article is dedicated to his memory.

\section{Author details}

${ }^{1}$ Dipartimento di Medicina Sperimentale e Chirurgia, Università di Roma Tor Vergata, Via Montpellier, 1, 00133 Rome, Italy. ${ }^{2}$ Emergency Care, Department of Intensive Care, Pain Medicine, and Anaesthesiology, Policlinico Tor Vergata, University of Tor Vergata, Rome, Italy. ${ }^{3}$ Fondazione Policlinico Tor Vergata, Via Oxford 83, Rome, Italy. ${ }^{4}$ Dipartimento di Scienze Cliniche e Medicina

Traslazionale, Università di Roma Tor Vergata, Via Montpellier, 1 - 00133, Rome, Italy.

Received: 4 November 2013 Accepted: 10 October 2014 Published online: 01 November 2014

\section{References}

1. Opstelten W, Mauritz JW, de Wit NJ, van Wijck AJM, Stalman WAB, van Essen GA: Herpes zoster and postherpetic neuralgia: incidence and risk indicators using a general practice research database. Fam Pract. 2002, 19:471-475 
2. di Luzio PU, Arpinelli F, Visonà G: Herpes zoster and its complications in Italy: an observational survey. J Infect 1999, 38:116-120.

3. Chidiac C, Bruxelle J, Daures JP, Hoang-Xuan T, Morel P, Leplege A, El Hasnaoui A, de Labareyre C: Characteristics of patients with herpes zoster on presentation to practitioners in France. Clin Infect Dis 2001, 33:62-69.

4. Hegalson S, Petursson G, Gudmundsson S, Sigurdsson JA: Prevalence of postherpetic neuralgia after a single episode of herpes zoster: prospective study with long term follow up. British Medical Journal 2000 321:1-4.

5. Gauthier A, Breuer J, Carrington D, Martin M, Rémy V: Epidemiology and cost of herpes zoster and post-herpetic neuralgia in the United Kingdom. Epidemiol Infect 2009, 137:38-47.

6. Yawn BP, Saddier P, Wollan PC, St Sauver JL, Kurland MJ, Sy LS: A population-based study of the incidence and complication rates of herpes zoster before zoster vaccine introduction. Mayo Clin Proc 2007, 82:1341-1349

7. Insinga RP, Itzler RF, Pellissier JM, Saddier P, Nikas AA: The incidence of herpes zoster in a United States administrative database. J Gen Intern Med 2005, 20:748-753.

8. Opstelten W, van Wijck AJM, van Essen GA, Van Essen GA, Buskens E, Bak AA, Kalkman CJ, Verheij TJ, Moons KG: The PINE study: rationale and design of randomised comparison of epidural injection of local anaesthetics and steroids versus care-as-usual to prevent postherpetic neuralgia in the elderly. BMC Anesthesiology 2004, 4:2.

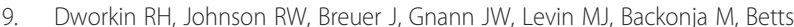
RF, Gershon AA, Haanpaa ML, McKendrick MW, Nurmikko TJ, Oaklander AL, Oxman MN, Pavan-Langston D, Petersen KL, Rowbotham MC, Schmader KE, Stacey BR, Tyring SK, van Wijck AJ, Wallace MS, Wassilew SW, Whitley RJ: Recommendations for the management of herpes zoster. Clin Infect Dis 2007, 44:S1-S26.

10. Jung BF, Johnson RW, Griffin DRJ, Dworkin RH: Risk factors for postherpetic neuralgia in patients with herpes zoster. Neurology 2004, 62:1545-1551.

11. Scott FT, Leedham-Green ME, Barrett-Muir WY, Hawrami K, Gallagher WJ, Johnson R, Breuer J: A study of shingles and the development of postherpetic neuralgia in East London. J Med Virol 2003, 70:S24-S30.

12. Nagasako EM, Johnson RW, Griffin DRJ, Dworkin RH: Rash severity in herpes zoster: correlates and relationship to postherpetic neuralgia. J Am Acad Dermatol 2002, 46:834-839.

13. Gabutti G, Franco E, Bonanni P, Conversano M, Ferro A, Lazzari M, Maggi S, Rossi A, Scotti S, Vitale F, Volpi A, Greco D: Reducing the burden of Herpes Zoster in Italy. Hum Vaccin Immunother 2014, Aug 7;11(1). [Epub ahead of print] PubMed PMID: 25115196

14. Levin MJ, Gershon A, Dworkin RH, Briston M, Stanberry L: Prevention strategies for herpes zoster and post-herpetic neuralgia. J Clin Virol 2010, 48:S14-S19.

15. Volpi A, Gatti A, Pica F, Bellino S, Marsella LT, Sabato AF: Clinical and psychosocial correlates of post-herpetic neuralgia. J Med Virol 2008, 80(9):1646-1652.

16. Gatti A, Pica F, Boccia MT, De Antoni F, Sabato AF, Volpi A: No evidence of family history as a risk factor for herpes zoster in patients with post-herpetic neuralgia. J Med Virol 2010, 82(6):1007-1011.

17. Parruti G, Tontodonati M, Rebuzzi C, Polilli E, Sozio F, Consorte A, Agostinone A, Di Masi F, Congedo G, D'Antonio D, Granchelli C, D'Amario C, Carunchio C, Pippa L, Manzoli L, Volpi A, VZV Pain Study Group: Predictors of pain intensity and persistence in a prospective Italian cohort of patients with herpes zoster: relevance of smoking, trauma and antiviral therapy. BMC Med 2010, 11(8):58.

18. Nagel MA, Choe A, Cohrs RJ, Traktinskiy I, Sorensen K, Mehta SK, Pierson DL, Tyring SK, Haitz K, Digiorgio C, Lapolla W, Gilden D: Persistence of varicella zoster virus DNA in saliva after herpes zoster. J Infect Dis 2011, 204(6):820-824

19. Tseng HF, Chi M, Smith N, Marcy SM, Sy LS, Jacobsen SJ: Herpes zoster vaccine and the incidence of recurrent herpes zoster in an immunocompetent elderly population. J Infect Dis 2012, 206(2):190-196.

20. Gershon AA: The history and mystery of VZV in saliva. J Infect Dis 2011 , 204(6):815-816.

21. Oxman MN, Levin MJ, Johnson GR, Schmader KE, Straus SE, Gelb LD, Arbeit RD, Simberkoff MS, Gershon AA, Davis LE, Weinberg A, Boardman KD, Williams HM, Zhang JH, Peduzzi PN, Beisel CE, Morrison VA, Guatelli JC, Brooks PA, Kauffman CA, Pachucki CT, Neuzil KM, Betts RF, Wright PF, Griffin MR, Brunell P, Soto NE, Marques AR, Keay SK, Goodman RP, et al: A vaccine to prevent herpes zoster and postherpetic neuralgia in older adults. N Engl J Med 2005, 352(22):2271-2284
22. Cunningham AL, Dworkin RH: The management of post-herpetic neuralgia. British Medical Journal 2000, 321(7264):778-779.

23. Johnson RW, Rice AS: Postherpetic Neuralgia. N Engl J Med 2014, 371(16):1526-1533.

24. Stein AN, Britt H, Harrison C, Conway EL, Cunningham A, Macintyre CR: Herpes zoster burden of illness and health care resource utilisation in the Australian population aged 50 years and older. Vaccine 2009, 27:520-529.

25. Dworkin $\mathrm{RH}$ : Inadequate evidence for a revised definition of postherpetic neuralgia (PHN). PAIN ${ }^{\circledast} 2007,128: 189-190$

26. Hope-Simpson RE: Postherpetic neuralgia. J R Coll Gen Pract 1975 25:571-575

27. Klompas M, Kulldorff M, Vilk Y, Bialek SR, Harpaz R: Herpes zoster and postherpetic neuralgia surveillance using structured electronic data. Mayo Clin Proc 2011, 86:1146-1153.

28. Petersen KL: Response to letter to the editor by Robert Dworkin. PAIN ${ }^{\circledR}$ 2007, 128:190-192.

29. Kawai K, Gebremeskel BG, Acosta CJ: Systematic review of incidence and complications of herpes zoster: towards a global perspective. BMJ Open 2014, 4(6):e004833. doi: 10.1136/bmjopen-2014-004833. PubMed PMID: 24916088; PubMed Central PMCID: PMC4067812

30. Yawn BP: Post-shingles neuralgia by any definition is painful, but is it PHN? Mayo Clin Proc 2011, 86:1141-1142.

31. Johnson RW, Bouhassira D, Kassianos G, Leplège A, Schmader KE, Weinke T: The impact of herpes zoster and post-herpetic neuralgia on quality-of-life. BMC Med 2010, 8:37.

32. Helgason S, Petursson G, Gudmundsson S, Sigurdsson JA: Prevalence of postherpetic neuralgia after a first episode of herpes zoster: prospective study with long term follow up. British Medical Journal 2000, 321:794-796.

33. Oster G, Harding G, Dukes E, Edelsberg J, Cleary PD: Pain, medication use, and health-related quality of life in older persons with postherpetic neuralgia: results from a population-based survey. J Pain 2005, 6:356-363.

34. Bouhassira D, Chassany O, Gaillat J, Hanslik T, Launay O, Mann C, Rabaud C, Rogeaux O, Strady C: Patient perspective on herpes zoster and its complications: an observational prospective study in patients aged over 50 years in general practice. PAIN ${ }^{\circledR} 2012,153: 342-349$.

35. McKendrick MW, Ogan P, Care CC: A 9 year follow up of post herpetic neuralgia and predisposing factors in elderly patients following herpes zoster. J Infect 2009, 59(6):416-420.

36. Hempenstall K, Nurmikko TJ, Johnson RW, A'Hern RP, Rice AS: Analgesic therapy in postherpetic neuralgia: a quantitative systematic review. PLOS Med 2005, 2(7):e164.

37. Coplan PM, Schmader K, Nikas A, Chan IS, Choo P, Levin MJ, Johnson G, Bauer M, Williams HM, Kaplan KM, Guess HA, Oxman MN: Development of a measure of the burden of pain due to herpes zoster and postherpetic neuralgia for prevention trials: adaptation of the brief pain inventory. J Pain 2004, 5:344-356.

38. Bouhassira D, Attal N, Alchaar H, Boureau F, Brochet B, Bruxelle J, Cunin G, Fermanian J, Ginies P, Grun-Overdyking A, Jafari-Schluep H, Lantéri-Minet M, Laurent B, Mick G, Serrie A, Valade D, Vicaut E: Comparison of pain syndromes associated with nervous or somatic lesions and development of a new neuropathic pain diagnostic questionnaire (DN4). PAIN ${ }^{\circledR} 2005$, 114:29-36.

39. Treede RD, Jensen TS, Campbell JN, Cruccu G, Dostrovsky JO, Griffin JW, Hansson P, Hughes R, Nurmikko T, Serra J: Neuropathic pain: redefinition and a grading system for clinical and research purposes. Neurology 2008, 70(18):1630-1635.

40. Apolone G, Mosconi P, Quattrociocchi L, Gianicolo EAL, Groth N, Ware JE Jr: Questionario sullo stato di salute SF-12, Versione italiana IRFMN 2005. Milano: Copyright 2001 Istituto di Ricerche Farmacologiche Mario Negri; Milano. http://crc.marionegri.it/qdv/downloads/SF12\%20Manuale.pdf

41. Kodraliu G, Mosconi P, Groth N, Carmosino G, Perilli A, Gianicolo EA, Rossi C, Apolone G: Subjective health status assessment: evaluation of the Italian version of the SF-12 Health Survey. Results from the MiOS Project. Epidemiol Biostat 2001, 6(3):305-316

42. Breivik H, Collett B, Ventafridda V, Cohen R, Gallacher D: Survey of chronic pain in Europe: prevalence, impact on daily life, and treatment. Eur J Pain 2006, 10(4):287-333.

43. Hall GC, Morant SV, Carroll D, Gabriel ZL, McQuay HJ: An observational descriptive study of the epidemiology and treatment of neuropathic pain in a UK general population. BMC Fam Pract 2013, 14:28. 
44. Reda H, Greene K, Rice FL, Rowbotham MC, Petersen KL: Natural history of herpes zoster: Late follow-up of 3.9 years $(n=43)$ and 7.7 years $(n=10)$. PAIN ${ }^{\otimes}$ 2013, 154(10):2227-2233.

45. Dworkin RH, Schmader KE: Epidemiology and natural history of herpes zoster and postherpetic neuralgia. In Herpes zoster and postherpetic neuralgia. 2nd edition. Edited by Watson CPN, Gershon AA. New York: Elsevier Press; 2001:39-64.

46. Volpi A, Gatti A, Serafini G, Costa B, Suligoi B, Pica F, Marsella LT, Sabato E, Sabato AF: Clinical and psychosocial correlates of acute pain in herpes zoster. J Clin Virol 2007, 8(4):275-279.

47. Johnson RW, Dworkin RH: Treatment of herpes zoster and posherpetic neuralgia. British Medical Journal 2003, 326:748-750.

48. Puchhammer-Stockl E, Aberle SW, Heinzl H: Association of age and gender with alphaherpesvirus infections of the central nervous system in the immunocompetent host. J Clin Virol 2012, 53(4):356-359.

49. Torcia MG, Nencioni L, Clemente AM, Civitelli L, Celestino I, Limongi D, Fadigati G, Perissi E, Cozzolino F, Garaci E, Palamara AT: Sex differences in the response to viral infections: TLR8 and TLR9 ligand stimulation induce higher IL 10 production in males. PLOS One 2012, 7(6):e39853.

50. Petersen KL, Rowbotham MC: Natural history of sensory function after herpes zoster. PAIN ${ }^{\circledR} 2010,150: 83-92$

51. Thyregod HG, Rowbotham MC, Peters M, Possehn J, Berro M, Petersen KL: Natural history of pain after herpes zoster. PAIN ${ }^{\otimes} 2007,128(10): 148-156$.

52. Gialloreti LE, Merito M, Pezzotti P, Naldi L, Gatti A, Beillat M, Serradell L, di Marzo R, Volpi A: Epidemiology and economic burden of herpes zoster and post-herpetic neuralgia in Italy: a retrospective, population-based study. BMC Infect Dis 2010, 3(10):230.

53. Mueller NH, Gilden DH, Cohrs RJ, Mahalingam R, Nagel MA: Varicella zoster virus infection: clinical features, molecular pathogenesis of disease, and latency. Neurol Clin 2008, 26(3):675-697.

54. Bridges D, Thompson SW, Rice AS: Mechanisms of neuropathic pain. $\mathrm{Br} J$ Anaesth 2001, 87(1):12-26.

55. Nalamachu S, Morley-Forster P: Diagnosing and managing postherpetic neuralgia. Drugs Aging 2012, 29(11):863-869.

56. Quinlivan ML, Ayres KL, Kelly PJ, Parker SP, Scott FT, Johnson RW, Maple C, Breuer J: Persistence of varicella-zoster viraemia in patients with herpes zoster. J Clin Virol 2011, 50(2):130-135

57. Kimura $H$, Ito $Y$, Suzuki $R$, Nishiyama $Y$ : Measuring Epstein-Barr virus (EBV) load: the significance and application for each EBV-associated disease. Rev Med Virol 2008, 18(5):305-319.

58. Mainka C, Fuss B, Geiger H, Höfelmayr H, Wolff MH: Characterization of viremia at different stages of varicella-zoster virus infection. J Med Virol 1998, 56(1):91-98.

59. Gershon AA, Chen J, Davis L, Krinsky C, Cowles R, Reichard R, Gershon M: Latency of varicella zoster virus in dorsal root, cranial, and enteric ganglia in vaccinated children. Trans Am Clin Climatol Assoc 2012, 123:17-33.

60. Pierson DL, Mehta SK, Gilden D, Cohrs RJ, Nagel MA, Schmid DS, Tyring SK: Varicella zoster virus DNA at inoculation sites and in saliva after Zostavax immunization. J Infect Dis 2011, 203(11):1542-1545

61. Mahalingam R, Wellish M, Brucklier J, Gilden DH: Persistence of varicella-zoster virus DNA in elderly patients with postherpetic neuralgia. J Neurovirol 1995, 1(1):130-133

62. Gilden DH, Gesser R, Smith J, Wellish M, Laguardia JJ, Cohrs RJ, Mahalingam R: Presence of VZV and HSV-1 DNA in human nodose and celiac ganglia. Virus Genes 2001, 23(2):145-147.

63. Gilden DH, Cohrs RJ, Mahalingam R: VZV vasculopathy and postherpetic neuralgia: progress and perspective on antiviral therapy. Neurology 2005, 64(1):21-25

64. Vafai A, Wellish M, Gilden DH: Expression of varicella-zoster virus in blood mononuclear cells of patients with postherpetic neuralgia. Proc Natl Acad Sci USA 1988, 85(8):2767-2770.
65. Schünemann S, Mainka C, Wolff MH: No acute varicella-zoster virus replication in peripheral blood mononuclear cells during postherpetic neuralgia. Acta Virol 1999, 43(6):337-340.

66. Kost RG, Straus SE: Postherpetic neuralgia-pathogenesis, treatment, and prevention. N Engl J Med 1996, 335(1):32-42

67. Whitley RJ, Volpi A, McKendrick M, Wijck A, Oaklander AL: Management of herpes zoster and post-herpetic neuralgia now and in the future. J Clin Virol 2010, 48(Suppl 1):S20-S28.

doi:10.1186/s12879-014-0556-6

Cite this article as: Pica et al:: One-year follow-up of patients with long-lasting post-herpetic neuralgia. BMC Infectious Diseases 2014 14:556.

\section{Submit your next manuscript to BioMed Central and take full advantage of:}

- Convenient online submission

- Thorough peer review

- No space constraints or color figure charges

- Immediate publication on acceptance

- Inclusion in PubMed, CAS, Scopus and Google Scholar

- Research which is freely available for redistribution

Submit your manuscript at www.biomedcentral.com/submit
C Biomed Central 